The final part of the book is the epilogue entitled "Surviving Childhood", in which the author shares her thoughts on the importance of literature in children's lives. She sees literature as an opportunity to keep memories, relate stories to pleasant times from the past, and imagine things which are unreachable or far away. For these reasons, children should be encouraged to read, which will equip them with the skills necessary to create their own associations with reading and creating their own worlds.

Finally, The Courage to Imagine demonstrates how literature can influence children's thinking and help them cope with the world around them. Dealing with topics present in everyday life, such as ethnic diversity, fear, bullying, or empathy, and offering examples of child heroes who overcome their problems, this book will be engaging to teachers and students, as well as experts in the field of children's literature. Its simple message that through reading children "can escape the adult world and imagine alternatives" (108) should be sufficient incentive for everybody to immerse themselves in reading and to start imagining.

Josipa Hotovec

\title{
Walt Disney and the Power of Music
}

James Bohn. 2017. Music in Disney's Animated Features: Snow White and the Seven Dwarfs to The Jungle Book. Jackson, Mississippi: University Press of Mississippi, 294 pp. ISBN 978-1-4968-1214-8

DOI: 10.21066/carcl.libri.2018-07(01).0008

"The essence of a Disney animated feature is not drawn by pencil [...]. Rather, it is written in notes", states James Bohn in the conclusion to his 2017 book Music in Disney's Animated Features: Snow White and the Seven Dwarfs to The Jungle Book (201). Published by the University Press of Mississippi with a forward written by director, producer, and writer Jeff Kurtti, the book gives profound insight into the Disney music legacy. With the exception of Fantasia (1940), which has been omitted since it does not contain original musical material, Bohn's monograph presents all the important musical scores produced by the Walt Disney Studios during Walt Disney's lifetime, from shorts about Mickey Mouse to The Sword in the Stone (1963) and The Jungle Book (1967).

The nine chapters which chronologically follow the creation of Disney's animated films gradually establish a recognisable scheme. Each chapter provides general information about the movie in question, for instance when the rights to the book (if any) were secured, how the idea was originated and developed, who was considered to write the music and songs, etc. Bohn then presents the life and work of one of Disney's composers. Providing interesting insights, the author explains that the first Disney composers mostly did not come from the highbrow world of classical music (which was the case in classical Hollywood liveaction films from the same period); instead, Disney leaned on men who knew something or little about music - some of them were animators (like Wilfred Jackson), some of them were music performers who had never considered composing for the movies before they met Disney (such as Carl Stalling or Frank Churchill). Educated musicians, such as Leigh Harline, Paul J. Smith, or Edward Plumb, joined Disney much later and were mostly used as orchestrators and arrangers, while the actual task of composing was left to the skilled 
melody makers who could write music that would appeal to both children and grown-ups with different backgrounds.

The parts of Bohn's book dedicated to the music itself in the animated movies contain some very interesting observations. On many occasions, Bohn provides serious harmonic and melodic analyses which are combined with visuals. The idea of wishing and dreaming in Snow White and the Seven Dwarfs (1937), for example, is accomplished through harmony and melodic contour. Moreover, this movie - which is known as the very first feature-length animated film - required enormous effort and became a kind of role model for many other of Disney's full-length animated films. For example, Bohn discovers that Snow White and the Seven Dwarfs uses rhymed dialogue (a kind of recitative) to allow characters to smoothly transition into a song. Also, the film's soundtrack contains leitmotifs which often emerge from the song's themes. The so-called Mickey-Mousing technique is included in almost every single Disney score to accompany gags, but also to establish characters. These and other "tricks" worked well with the audience, so Disney encouraged his music staff to use them in similar situations. Therefore, Bohn often draws parallels between different songs from different animated films, discovering similarity between "wishing" and "dreaming" songs, animals" "working" songs and others in Snow White, Pinocchio (1940), Bambi (1942), Cinderella (1950) and Sleeping Beauty (1959).

Far from allowing his staff to copy from older films, Disney was always open to different and new solutions. Bohn dedicates many pages to the more classical-sounding score for Bambi, the unusually dissonant cue in “The King's Plan" (Cinderella), or Disney's decision not to use Mickey-Mousing at all in Sleeping Beauty.

At the end of the part dealing with scores and songs, Bohn gives a list of unused songs, which is sometimes considerably long (as in the case of Snow White and the Seven Dwarfs) or interestingly short (as in the case of The Sword in the Stone, 1963).

In the Reception and Summary section, Bohn shows each film's aftermath: whether the premiere was successful or not, whether the film became a box-office hit or not, the critical response, etc. In this part, Bohn often shows Disney as self-critical, searching for reasons for the (possible) failure of a particular movie in his and his staff's decisions, often ascribing it to the bad treatment of the emotional content of the story. Of course, if the movie was successful (as Snow White and the Seven Dwarfs was), it always gave him wings to expand, invest, and experiment with something new and unexpected.

These sections of the chapter(s) also list songs from individual movies, sung or arranged by popular musicians. This reviewer's favourite is the author's assertion that the rhymed dialogue preceding Snow White's "I'm Wishing" - "Do You Want to Know a Secret? Promise Not to Tell?" - was used by John Lennon in the Beatles song of the same name. There are, of course, many more.

James Bohn gives his readers more than just detailed lists of unused songs and songs covered by other artists; in the Appendix, he also provides a detailed list (in tabular form) of every single cue which appeared in Disney's feature-length animated movies. The table contains the number of each cue, its title, duration, and the names of the composers who created it. The list mostly comes from cue sheets created by the Disney Music Group. It provides valuable information, not just about the number and titles of the cues used, but also about the names of the composers involved, since there were often several of them working 
on the same film and even on the same cue. Bohn also lists the exact duration of the film and music, leading readers to the stunning conclusion that in many Disney films, the music lasts almost as long as the visuals (in many cases, there is less than a minute difference in the duration of the visual and music track).

Music in Disney's Animated Features is not wholly an easy read. Its author spent a great amount of time doing research in the archives of (among others) the Carl W. Stalling Papers in the American Heritage Centre at the University of Wyoming and the Disney Music Legacy Library. Detective work of a kind was necessary for the early parts of the book, because many important questions - the answers to which have often been taken for granted - could only be answered with the help of archival materials. Yet, it is still surprising that the author of music for the first animated sound film, Steamboat Willie (1928), is unknown, or that the name of the orchestra conductor for Snow White and the Seven Dwarfs is not certain. Besides, what was Frank Churchill's first musical score in the Disney Studios? The author raises and tries to answer these questions by finding "evidence" in musical excerpts from manuscripts, specific cues, leitmotifs, even patents (in Carl Stalling's case) and photographs.

In addition to his musicological "digging" in archives, Bohn occasionally meticulously analyses songs and parts of the score, mostly using Heinrich Schenker's and Allen Forte's approach. Nevertheless, he did not write a book of musical analyses, which would be impossible to understand or, at least, difficult for readers without a formal musical education. Instead, the author cleverly combines his specialised expertise, impressive boxoffice figures, newspaper reports, and explanations of visuals in order to reach a much broader audience.

The only thing that could possibly have been done differently is the weight given to chronology. In its eagerness to trace Disney's journey from an enthusiastic owner of a small studio to a highly innovative artist who inspired and guided not only his animators but also his composers and songwriters, Bohn's book on Disney's music (and also those of many other authors) presents it in chronological order. Bohn does try to break out of this kind of formal cage by comparing songs from different movies - their structure, their lyrics, their melodies and harmonies in conjunction with the visuals. This type of parallel approach to similar songs and scores from different Disney animated features, which enabled the author to detect common composing techniques (e.g. Mickey-Mousing, rhymed dialogue, song archetypes, etc.) could be a way to escape formal chronology. The next step would be writing a book which involves parallel comparison/description/analysis of the same or similar musical material which has already been identified as characteristic of Disney. The task is not easy, but Walt Disney was never put off by difficulties. Neither should his scholars. 